\title{
Complexity in China's current role in multilateral orders
}

\author{
Suzanne Xiao Yang ${ }^{1}$
}

Received: 8 July 2020 / Accepted: 31 October 2020 / Published online: 22 November 2020

(c) The Institute of International and Strategic Studies (IISS), Peking University 2020

\begin{abstract}
Rather than the prescribed scenario of a Thucydides Trap or a Kindleberger Trap, the global system will see a Transitional Reformation process of contestation and cooperation as power transitions from North America and Europe towards Asia and other regions. While acknowledging that power increasingly diffuses from state actors to transnational civil societies and private sectors, this article contends that, in a state-centric global system, it remains significant that US-China competition, and the wider competition, contestation and renegotiation of power relations between established and rising powers, takes place within United Nations multilateral frameworks. In addressing China's role, potential, and limits in the dynamics of renegotiation, this article identifies three layers, or subprocesses, of complexity in the current role China plays in multilateral orders in flux.
\end{abstract}

Keywords United Nations · China-US relations $\cdot$ Norms $\cdot$ Multilateral orders

\section{Introduction}

Deterioration of the relationship between China and the United States has seen economic calamities with global implications, negatively impacting the functioning of multilateral institutions. Recently, hostility between two of the five permanent members of the UN Security Council (P5) has intensified, as tensions have flared concerning the origins of the coronavirus and the role of the World Health Organization (WHO) in managing the pandemic. In general, the split among the P5, with China and Russia on one side, and the United States on the other, has resulted in the United Nations entering a chaotic state in which it is unable to function properly. ${ }^{1}$ Faced with Covid-19, "the most challenging crisis since the Second World War"

\footnotetext{
1 In late March 2020, for instance, the UN Security Council failed to adopt a draft resolution responding to Secretary General Antonio Guterres's widely echoed call to "protect vulnerable civilians in conflict zones with an immediate global ceasefire" (UNSG 27 March 2020; International Crisis Group 27 March 2020).
}

Suzanne Xiao Yang

suzanne.yang@balliol.oxon.org

1 C/O Balliol College, University of Oxford, Oxford OX1 3BJ, United Kingdom 
(Guterres, 2020 UNSG, 27 March 2020; Gladstone 2020), the United Nations has shown little prowess for taking coordinated action, although it has been the world body instrumental in managing "problems without passports" (Annan 2009), from global warming, terrorism to pandemic. Nor has the world's most important global international organization taken any initiative to help address, let alone mitigate, the economic and political repercussions of the coronavirus pandemic. This is in sharp contrast to the UN's appetite and aptitude for action in the last 30 years, tarnishing its image and casting doubts about its relevance.

Few observers dispute that relations among great powers carry high stakes-historically, such relationships have led to peace or war, prosperity or failure. The Concert of Europe, through its multilateral forums and procedural principles for solving problems of collective action, has conducted conferences and consultations on international issues including territorial boundaries, achieving peace for most of the nineteenth century. Power contestation on a regional or global scale, coupled with failed diplomacy and broken international institutions, however, has repeatedly escalated to catastrophe, saliently the two world wars in the twentieth century. The post-WWII international order, led by the United States with its allies, has enjoyed lasting peace of seven decades across much of the globe. Essential to this peacemaking has been the collective security system managed by a concert of great powers through the United Nations Security Council, as well as the multilateral economic system, with the Bretton Woods institutions of the World Bank and International Monetary Fund, and the General Agreement on Tariffs and Trade-later the World Trade Organization. The United Nations has achieved an "unprecedented degree of success," including its "contribution to decolonization" and the promotion of selfgovernance (Roberts 2003, 49). In the last decade of the twentieth century, a fundamental geopolitical shift took place, largely peacefully, marking the end of the Cold War and a bipolar system. Multilateral norms and institutions triumphed. With a great degree of continuity in the principles for multilateral institutions on the one hand, and the dynamics and momentum for actual or aspired institutional change on the other, the post-Cold War world has been variously described as unipolar, nonpolar, multipolar, and disorder or chaos from which a new order may emerge.

Realist pundits and strategic thinkers who have warned of a Thucydides Trap envision a scenario in which major military conflict erupts between the world's two largest economies (Allison 2015, 2018; Mearsheimer 2010; Kirshner 2019). Where major war is thought unlikely for reasons of economic interdependence and/or nuclear deterrence, as liberal institutionalists suggest, there may be a strategic challenge, a Kindleberger Trap. Joseph Nye (Nye 2017, 2020), with others, posits the possibility that as the United States withdraws its leadership role from the evolving global order, and reduces or attempts to stop providing global public goods, China would be unwilling to step in to assume global leadership. Such a moment of "the United States couldn't and China wouldn't" (Nye 2020, 16), paralleling Kindleberger's epigrammatic "Britain couldn't but the US wouldn't" (describing the failure in global cooperation to control the Great Depression in 1933, Morrison 1993), would leave a gap in global institutions no state is yet prepared to fill.

A Thucydides Trap or a Kindleberger Trap, underlined by notions of power transitions and hegemonic succession, however, is neither a sufficient explanation nor 
convincing foresight for all observers, international actors and policy analysts. The issue is not so much that the United States, by far still the world's most powerful state, could not, like Britain in the 1930s. The matter is more fatigue by the United States in its commitment to providing global public goods, magnified by the incumbent federal administration, which has not manifested the political will to take on leadership of global problems. Though China may wish to occupy a prestigious position from which to lead in collective decision-making (Xi 2017; Lee Kuan Yew in Allison et al. 2013; Kissinger and Goldberg 2016; Shi 2015; Tasdall 2019), the question remains whether it is capable of assuming anything similar to the US role, or even one balancing U.S. dominance in coalitions or alliances. Instead of a scenario that involves major war or in which "the US couldn't and China wouldn't," there is the possibility that "the United States could but wouldn't, where China would but couldn't." This may be termed a Transitional Reformation scenario, in which international society experiences a process of institutional reforms to meet the requirements of the changing realities of power diffusion, from the West to Asia, and to a certain extent also from state actors to non-state actors.

This article takes up this third scenario and directs attention to the important role multilateral principles and global institutions perform in managing power diffusion. To highlight a few observations about the ways - and, importantly, the current shortage of ways-China and the United States can successfully emerge from this dilemma, which has historically trapped nations that possessed both power and the willingness to deploy power in global institutions, this article unpacks the complexity of China's current role in multilateral orders in flux.

To unpack this complexity, one must consider the following questions: To what extent has China's behavior in multilateral orders been consistent with procedural and substantive norms and principles? What differences has China's participation made in UN's primary functions of maintaining world peace? In what ways has China influenced a political process of bargaining and negotiation among UN members? Where do China's limits lie in key UN decisions? For China to perform a constructive role in shaping the workings of the existing UN system, and in influencing processes of norm diffusion, it must manage complex and ongoing tensions between cooperation and contestation with multiple actors in international society. It also very much depends on how the United States chooses to interpret and act regarding the reality of China's behavior, and what long-term and immediate goals the United States sets out for its own foreign policy in managing changes in global power relations. In other words, one must also assess how the United States approaches UN multilateral frameworks.

In answering some of the above questions, the approach taken here is, rather than focusing on China alone, to examine China's behavior by comparing the level of consistency of US foreign policy behavior with existing rules and norms, with that of China, in the context of global diffusion of power and norms. This is because the United States has been the most influential player in twenty-first century multilateral orders, and it is essential to understand the evolution of China's behavior as at least in part a response to US behavior. Additional insight is gained by analyzing ChinaUS interactions in this context, in contrast with the US official narrative of rising powers as revisionist. 


\section{Patterns in China's and United States' behavior in multilateral orders and the evolution of China's stance}

From an institutionalist point of view, multilateral organizations function in managing global economy and security thanks to the existing regulatory framework, although power politics is at work all the time. In this view, "the facilitative institutions of multilateralism" are not the result of international society but the cause to its growth in the post-war world order (Kratochwil 1993,51; Burley 1993). Scholarly writings on multilateralism abound (Keohane 2002; Kahler 1992; Contessi 2014), in which the term "multilateral orders" is often replaced with its singular form (Ruggie 1992; Keohane 2002; Clark 2014; Hurrell 2007a). In this article, the plural form is used to emphasize that state relations matter in various institutional frameworks, of trade, economy, security, finance, and climate, among other dimensions of the global system. Multilateral orders are forums for state interaction and platforms for collective decision-making and action, all with generalized principles and norms.

China's multilateral behavior has changed over time. By the early 1980s, China had adopted a "reactive minimalist strategy of symbolistic diplomacy" in the United Nations (Kim 1979 Yang 2014, 61). It had maintained a reactive satisficing strategy in the 1990s, increasing engagement since the start of this century. Over the last decade or so, China has taken an active stance in the United Nations to realize milieu goals (Yang 2014, 187; Kim 1979, 1998). Samuel Kim notes that in group consultations and debates in the 1970s, China never invoked any of the multilateral treaties, except the UN Charter itself, because China was not convinced that non-Western countries could benefit from UN multilateral arrangements (Kim 1979, 429). Over time, China's behavior has displayed an increasing alignment with global norms.

The first layer of complexity of China's current role in multilateral orders lies in the ways in which China behaves, particularly in the process of power diffusion, as a response to US behavior or in taking initiative. A compelling analysis that Rosemary Foot and Andrew Walter have conducted of norm compliance on the parts of China and the United States in the most recent decade identifies important behavior patterns of the two states across five global normative frameworks (Foot and Walter 2011, 1). It shows that in four of the five issue areas in question, "China has moved from a position of generally low behavior consistency towards gradually higher levels of consistency", namely, in the use of force, nuclear non-proliferation, climate change, and financial regulations. The only area that has seen levels of consistency fall from already moderate levels is macroeconomic policy surveillance, where China accepted the greater exchange rate flexibility that the International Monetary Fund (IMF) demanded but was reluctant to agree to the accelerated appreciation of the Renminbi (RMB) that would jeopardize domestic social stability as well as the economy (Foot and Walter 2011, 275, 110). Iain Johnston's most recent work about China's conformity in global orders discloses that, in a similar vein, in eight global normative frameworks, from military, environment, to trade and information, China's support for rule-based orders 
is medium to high in various ways, as "China interacts differently with different orders, supportive of some, unsupportive of others, and partially supportive of still others", "[t]he empirical evidence across these different orders" suggests that "China is not challenging the so-called liberal international order" but operates within it (Johnston 2019, 12).

In contrast, US conformity to normative frameworks is low to mixed (Foot and Walter 2011; Hurd 2007). The Bush Doctrine of preemption, a major departure from the core tenet of international law on the use of force, marked an unprecedented tendency towards behavioral inconsistency across a number of issue areas. The Trump administration's decision to withdraw from the Paris climate agreement, rolling back President Obama's leadership efforts in helping forge the global effort, as well as the Trump administration's attitude to the UN Human Rights Council, UNESCO and the Iran nuclear agreement has shown a US "tendency to depart periodically from global norms that it has helped to establish". As Foot and Walter observe, selectivity and inconsistency have characterized the US stance towards global norms, particularly at times when "global regimes may require more of the US than other countries" and expectations may be high of US behavior. The United States "has sometimes chosen to exercise force unilaterally, to overlook the nuclear weapons capacities of friendly states, or to ignore IMF advice to reduce its fiscal deficits" (Foot and Walter 2011, 275).

In the absence of counterweights since the end of Cold War, the United States "has behaved as unchecked powers have usually done" (Waltz 2000, 24). It has been able to "exert substantial leverage over other states" within the multilateral framework (in the UN, IMF), to reshape them to achieve its instrumental goals, or "to shift costs onto other states" in existing or new groupings such as the G7 and the G20 (Foot and Walter 2011, 290; Scheweller 2018). At the same time, as Foot and Walter $(2011,278)$ have noted, "the formal constraints imposed by global normative frameworks on the United States are generally no greater than those that apply to other developed countries, most of which do not enjoy America's global influence."

On "the skewed distribution" of power in the post-Cold War international society, Thomas Weiss in 2012 characterized the United States as almost a parallel "world organization" with its global reach, and dominance by way of its economic, military and soft power, whereas the United Nations enjoys its global reach mainly with its membership and scope (Weiss 2012, 4-6). Weiss compares UN debates and policy deliberations with Roman Senate's effort to control the emperor (Weiss 2012). The (re)emergence of China, along with the rise of new powers, such as India and Brazil, has not helped to keep a balance of power with the United States in the United Nations. While the Trump administration withdraws US leadership from multilateralism, rising powers, having mostly benefited from it, strongly support the UN system, along with established powers, namely Britain, Germany, France and Japan. Notwithstanding concerns about the representation problem entrenched in the initial design of the institutions, and the efforts to reform it, there is no wish to see the UN system collapse.

China's active participation in UN activities is the result of the UN system's effective function, and China's socialization into the system by more powerful counterparts within it (Zhang 1998, 2016; Ikenberry and Kupchan 1990; Hurrell 2007b; 
Ikenberry 2008). China regards the United Nations as the world's most authoritative and representative international organization, strongly favoring the legal sovereign equality of state that UN membership grants, and its corollary of non-interference in domestic affairs. As a permanent member of the UN Security Council, China enjoys the status and special rights that the hierarchical structures permit. With its growing economic power, China has increased its bearing of the burdens associated with its membership (Foot 2020). China's active participation in the UN system appears to be enhancing the UN, for instance, in peacekeeping and in UN development programs. China has expanded and diversified its role in peacekeeping. In March 2013, the Chinese Ministry of National Defense for the first time included "safeguarding world peace and regional stability" as one of the main missions for the People's Liberation Army in the twenty-first century (Information Office of the State Council of PRC 2013). In his first UN address in September 2015, President Xi announced China's contribution to the new UN peacekeeping capability readiness system; in his words, to "lead in setting up a permanent peacekeeping police squad and build a peacekeeping standby force of 8,000 troops" (UN News 2015). Sending one-fifth of the 40,000 total troops committed by 50 nations, as Reuters reporters commented at the time, was "a move that could make [China] one of the largest players in UN peacekeeping efforts" (Martina and Brunnstrom 2015). And it did. ${ }^{2}$ In addition, China committed to a new 10-year, \$1 billion USD China-UN peace and development fund for peacekeeping operations, and to sending $\$ 100$ million in military assistance to the African Union for five years "to support the establishment of an African standby force and to boost its capacity for crisis response" (Xi 2015a, b, c; UN News 2015).

Deployments of UN peacekeepers from the United States, the United Kingdom and Russia since 2000 have declined or remained static, and UN peacekeeping operations are underfinanced and overburdened (UN Peacekeeping website). China has increased its personnel deployment, including troops, police and military observers. It had 3084 personnel by mid-2015 and over 2500 personnel deployed in 2019, ranking first among the P5 of the UN Security Council. In a Foreign Affairs article titled, "How China can improve UN peacekeeping," Senior Colonel Zhou Bo (2017) from Chinese Ministry of National Defense, suggests that supporting UN peacekeeping operations helps boost China's prestige and promotes "an image" of China "as a responsible nation on a peaceful rise." "Increased involvement and more investment in the welfare of countries and peoples in need" has put China in a more important position to strengthen peace operations, contributing to stability and security in Africa and beyond (Pauley 2018). In so doing, China gains in knowledge-sharing and knowledge transfer through joint collaboration with other state actors in UN peacekeeping missions. A greater role in peacekeeping also helps China strengthen and modernize its military capacity by improving its Military Operations Other Than War (MOOTW).

\footnotetext{
${ }^{2}$ A year later, a 150-person Chinese police unit passed the UN selection process to serve as the first standby Formed Police Unit in UN's history. By November 2017, the PLA had organized a standby peacekeeping force of 19 units with 8000 troops.
} 
While China increases and diversifies its UN participation, it has also increased its financial contributions to both the UN's regular budget and peacekeeping operations. Of the entire UN budget, China contributed $12.5 \%$ in 2017, surpassing Japan at about $8.5 \%$ and becoming the second-largest single contributor, after the United States at 22\% (20\% in 2018). EU countries combined pay a total of approximately $30 \% .^{3}$ As to the UN peacekeeping budget, in March 2018, the United States announced that it would be reducing its contribution of $28.5 \%$ to no more than $25 \%$. In the same year, China increased its share, from $6.6 \%$ of 2016 to $10.3 \%$. The Trump administration has sought to trim down payments to peacekeeping and specialized agencies, including a cut of $20 \%$ from its funding to the WHO in 2018. ${ }^{4}$ In April 2020, amidst the coronavirus pandemic, the Trump administration announced it would suspend all funding to the WHO, while it conducts a review of the agency's handling of the crisis. WHO Director General Tedros Adhanom Ghebreyesus voiced regret at Washington's decision, stating WHO would work with other states to fill the funding gap. (Hinshaw and Alpert 2020).

\section{Narratives of revisionist and status quo powers and how China's behavior is perceived}

The narrative of post-WWII multilateralism posits a US-led, West-centered global order. The United States is both "the owner and the operator of the system"; nonWestern countries have been enmeshed, socialized and integrated, with "gradual and progressive diffusion of liberal values," into this order (Hurrell 2010, 139). Demonstrating an understanding of the dynamics of complex hierarchies in UN politics, China has built a capacity to achieve its goals, increasing its interests and influence within the system. Over time, China has gained a greater degree of confidence in its role in the United Nations and strengthened its commitment to UN activities, choosing to rise within the system towards great power status. The second layer of complexity for China playing a constructive role in multilateral institutions concerns how China's behavior is perceived globally, particularly by the United States, and how these two countries relate to and interact with each other.

China's activities in many regions of the world, along with its proclaimed commitment to UN multilateral frameworks, have elicited varying responses, including concern, particularly from the United States. Frequently juxtaposed in media reports and policy analyses on global order has been the narrative of China's rising status with the possibility of an end to US dominance. Perceived rivalries between the United States and China, ranging from economy to technology, and geostrategic terrains to cyberspace, risk irrevocable consequences. Uncertainty about how China

\footnotetext{
3 On the UN's 2020 regular budget, published on 13 May, China paid US\$336,780,502, Japan $£ 240,248,915$, Germany US\$170,844,920, UK US\$128,119,663 and France US\$124,192,194. The United States and Russia have not yet entered their amounts (UN 2020).

4 In 2001, Jesse Helms and Joseph Biden managed to reduce US share of the UN administration budget from 25 to $22 \%$, an effort to decrease payment to the UN, withholding US contribution to force reforms at the UN. (Marquis 2001; Shendruck et al. 2020).
} 
might exert its influence over the direction in which global politics evolves persists with Donald Trump's distain for global interdependence, his "America First" stance and his contention that "the world doesn't belong to globalists, it belongs to patriots" (Trump 2017, 2019). The 2017 US National Security Strategy (NSS) (White House 2017a, b, 25) articulated US frustration at China's failure to converge on US values: "For decades, U.S. policy was rooted in the belief that support for China's rise and for its integration into the post-war international order would liberalize China. Contrary to our hopes, China expanded its power at the expense of the sovereignty of others" (White House 2017a, b, 25). In the 2017 NSS and the 2018 National Defense Strategy (U.S. Department of Defense2018, 2), China, along with Russia, is labelled as a revisionist state, aiming "to shape a world antithetical to U.S. values and interests" (White House 2017a, b, 25). The Trump administration has selected China as its primary geopolitical competitor.

Anxieties about how China's global activity might influence the evolving global order notwithstanding, the Chinese government has not (yet) articulated viable alternative values other than reiterating their notions of national sovereignty, and their contentions about rights beyond borders. Even at the high point of antagonism between communism and capitalism, China's so-called revolutionary "antithesis" to multilateral orders was a rhetoric of justice for the Third World (Kim 1979). In contrast with American Exceptionalism and Ronald Reagan's US as "shining city upon a hill," China demonstrates little interest in or prowess for propagating its worldviews globally. "The Chinese do not strive for conversion. In their view, if you do not belong to Chinese culture, you can never become fully Chinese" (Kissinger and Goldberg 2016). In a similar vein, Singaporean public intellectual and UN veteran diplomat Kishore Mahbubani (2020) similarly suggests that China has no universalizing mission, and as there is no fundamental contradiction between America and China, "if both America and China adopt a more 'live and let live' policy, there's room for both to live in peace with each other."

In the global normative environment, states are not passive in the process of norm diffusion, nor do they act "out of a universal moral script to produce and direct" the process in global politics (Acharya 2004, 269; Hurrell 2007b). Rather, the acceptance of norms, and their internalization, involves a fitting in with domestic mainstream normative beliefs and practices (Acharya 2004; Checkel 2001; Finnemore and Sikkink 1998). China's experience as a beneficiary of the UN system has made it a staunch supporter of the system, and while China has not sought to rewrite the rules nor to reform the primary institutions, it is capable of advancing its preferences over the set of norms about state sovereignty and self-governance, to benefit from the norm's complementarities or to fit with its domestic priorities. The United States and its allies that emphasize the indivisibility of individual rights with a cosmopolitan moral consciousness, meet a China in the UN which, with its special status the UN's institutional design affords it, may choose to promote their own ideas in line with the pluralist norms found in the United Nations before the end of the Cold War (Foot 2020).

In his studies of strategies available to rising powers that seek to contest or challenge the existing order, Drezner $(2007 ; 2019 b, 505,523)$ avers that "the 'rational revisionist' response to upturning a global economic order requires a series of 
sequential moves, and the data strongly suggest that neither Russia nor China is making those moves." "The claim of Russia and China being challengers to the liberal economic order" has been overplayed; "Beijing has acted more like a supporter than a spoiler" (Drezner 2019b). In 2016, China launched a program with UN Department of Economic and Social Affairs: Jointly Building Belt and Road towards Sustainable Development Goals. Its long-held interest in advancing sustainable development, part of the objectives of the BRI, is now aligned with UN Sustainable Development Goals 2030 (Horvath 2016). Notwithstanding concerns voiced by some about the motivation of China's advancement, ${ }^{5}$ at the 2017 Belt and Road Forum, UN Secretary General António Guterres confirmed that the UN system would stand ready with China to achieve the SDGs (UNSG 2017). Two years later, he pledged the support of United Nations agencies, funds and programs operating in country, stating "the pillars of the Belt and Road Initiative link to the 17 SDGs, which include ending extreme poverty and hunger, can translate into 'reallife progress for people."” (UN News 2019).

The China-sponsored Asian Infrastructure Investment Bank (AIIB) initially appears to be an initiative challenging existing global financial institutions. The Obama administration was concerned that it would be a competitor to the World Bank. As it evolves, however, AIIB management has included a combination of members from Western and Asian countries. Conforming to multilateralist principles and aligning with the rules of existing institutions, "it functions as correctives of IMF's institutional failure or stagnation, to complement rather than compete" with the World Bank and Asian Development Bank. AIIB does not constitute any alternative normative framework, or work at cross-purposes with existing global institutions (Chin 2016; Kahler 2018; Quayle and Gao 2018; Chin 2019). Working with experts and professionals outside China, China has adjusted its initial positions and eventually created an AIIB that is different from its earlier design. The key factor in China changing its positions is the role of the international epistemic community (Zhao 2018, 656; Humphrey 2020, 3; Gu 2017). Many see this as an example of how existing multilateral frameworks and the transitional epistemic community have the power to "balance, influence, and shape" challenges from rising powers including China, and how multilateral institutions can act to "check rising powers revolutionary potential" making them play by the rules (Zhao 2018, 656).

The growing influence of China and other rising powers does not in itself signal the end of a US central role in multilateral orders. For scholars like Ian Clark, observers of continuity and change in international society for several decades, "any evidence of an actual decline in US influence is more likely a consequence of specific US policies than a result of any proactive Chinese policy to achieve such an outcome" and "the future of the US-Chinese relationship remains as much a function of the content of US policies as of any deterministic structural requirement for China to

\footnotetext{
5 For instance, commentators suggest that the alignment of BRI with UN Sustainable Development Goals 2030 constitutes "a strategic move to turn the UN [Chinese] tools" to realize its interests, suspecting this is a strategic step, not merely a development project, for China to revive a hegemonic position in Eurasia and beyond (Tung and Yang 2020).
} 
balance against American power" (2011, 22-23; Hurd 2007). For influential political economic analyst Drezner (2019b), "[t]he most rational revisionists of the current moment do not reside in any hegemonic challenger to the United States. They reside in Washington, D.C." If status grievances in international society, economic and technological ambitions, or complaints about procedural justice in multilateral institutions could trigger revisionist behavior, equally the world's "unchecked power serves no better engine to drive a status quo power," echoed Randall Schweller (2018, 40), the United States, as the only superpower, had engaged in "large-scale international revision in the system." It could be claimed that the United States has acted as a revisionist power only within particular moments with mitigating circumstances of the peculiarly disruptive governing elite. In Drezner's view, it remains the case that "the United States is the only country capable of subverting the liberal international order that it began to create more than seventy years ago" (2019a, 531).

\section{Norm diffusion and representation in multilateral institutional practice}

China's participation in the UN system, like that of other rising powers, is a journey characterized by adaptation and learning, with constant weighing of domestic and international demands in decision-making. Due to uneven state socialization between established powers and other states, new norms do not always find domestic fit among rising powers. China has been socialized into pluralist-liberal global norms, but incompletely into the newly developed solidarist liberal norms. China has learned the ways in which the mechanisms and procedures work while appearing to want to perform a constructive role in making new norms where possible or in interpreting new norms. In what ways has China's active participation impacted norm diffusion in multilateral frameworks? To what extent, if any, has China's increasing influence changed the nature and norms of multilateral orders?

The rationalist-functionalist notion of multilateralism holds that states join in multilateral frameworks for the benefits they cannot otherwise obtain. Thus, to manage the costs and risks of their international interdependence, states engaging in multilateralism find it imperative to strengthen global cooperation. In an essentially state-centric system, this process is often closely associated with political activism and responsiveness to global problems. So, on this logic, the United Nations works well when its multilateral arrangements and agencies are seen by the members as robust, and the rules and norms legitimate.

In the post-Cold War era, the normative structure of international society has moved in the direction of legal solidarism fostering "a cosmopolitan moral consciousness," resulting in a "denser and more integrated network of shared institutions" (Hurrell 2003, 39, 48). In this normative structure, the classical balance between state sovereignty and human right tilts towards the latter. The beginning of the new millennium witnesses an increase in the diffusion of power from North America and Europe toward Asia and other regions. As a consequence of both trends, the current political context for multilateral institutions is characterized by a broad range of normative preferences and interests that diverge among countries. 
There is often a gulf between the established and the rising powers, toward the norm of state sovereignty and human rights, with established powers emphasizing rights beyond national borders, and rising powers adhering to notions of self-governing and a distinction between the domestic and international.

A third layer of complexity of China's increasing role in multilateral orders lies in the paradox where as China seeks prestige, demonstrating that it is a responsible power, it "risks giving too much credence to the legitimacy of the existing social structure" and the relevant norms, which "it might otherwise prefer to modify or displace" (Clark 2014, 319; Zhang 1998). An increasing urge to promote its own preferences in multilateral frameworks needs to be balanced with the risk of being perceived as advancing alternative values in conflict with the evolution of solidarist global values.

China's effort to reinterpret the R2P, leading to the restrictions of its application, is a case in point illustrating how China opts to resolve the tension, through institutional mechanisms and procedures, between its traditional foreign policy of non-interference and the challenges posed by its growing global involvement and connections (Paal 2011). China's decision to abstain on the vote for UN Security Council resolution 1973 authorizing force in Libya, for instance, "was shaped by an unusual set of political and factual circumstances" (Garwood-Gowers 2012). The concept of "Responsible Protection," which China later proposed, drawing in part on Brazil's idea of "Responsibility while Protecting," "made a contribution to the debate over R2P's third pillar following the controversy over military intervention in Libya" (Garwood-Gowers 2016, 89; Chen 2016). The process of diffusing R2P has characterized the willingness of rising powers (China and Brazil) to assert their interests and normative preferences on non-intervention and state sovereignty.

Currently desirous to make positive contributions to UN activities, China seeks to gain international recognition, boost its prestige as a responsible power, and to help create "favourable conditions for China's development "with the concept of fairness and justice" (Xinhua 2015; Xi 2018). ${ }^{6}$ China has, since President Xi took office in 2012, become more confident than before in expressing its dissatisfaction at the gap between China's growing national strength and its status in the global system. Looking at IMF, for example, China has a 3.66 vote percentage in the IMF, less than the Benelux countries. The United States stalled a 2010 agreement to revise the voting allocations of the IMF. As of 2019, Brazil, Russia, India, China, and South Africa (BRICS) had $42 \%$ of the global population, $30 \%$ of the territory, $23 \%$ of GDP, and $18 \%$ of global trade. These countries seek a greater representation commensurate with their power in making economic and financial decisions in multilateral frameworks. AIIB's creation is in part a response to the problem of under-representation of rising powers in established global financial and monetary institutions. ${ }^{7}$

\footnotetext{
${ }^{6} \mathrm{Xi}$ made it clear at the 27th CCP Central Politburo study session that China should play a role in strengthening global governance to create favorable conditions for China's development (Xinhua 2015). In 2018, Xi said "China should lead the reform of global governance system with the concept of fairness and justice" (Xinhua 2018).

7 Whether the creation of regional multilateral organizations such as the AIIB represents multilateralism being diminished or contested, or a promising way to build global order by exploring regional initiatives that may complement older global organizations, remains to be seen. See among many others, Morse and Keohane (2014).
} 
As a latecomer to the UN system, the numbers and ranking of UN civil servants from China fall short in terms of the desirable ranges, for the factors of membership, population and contribution, as stipulated by the UN General Assembly. In the UN Secretariat, China ranked 14 among all 193 member states in terms of the number of civilian employees. Among staff in key UN organizations, China has fewer representatives than countries like India, Pakistan and Brazil. Since the end of the Cold War, the United States, Britain, and France have held the most influential positions in the UN Secretariat. As of 2016, there were 11 Chinese nationals occupying D1 or above level posts in the UN Secretariat, United States nationals occupying 50, UK 24 , and France 17, and these numbers haven't since changed. ${ }^{8}$ In contrast, China's representation in upper ranks has been improving gradually. Of the $15 \mathrm{UN}$ specialized agencies, Chinese nationals currently head the Food and Agricultural Organization (FAO), the International Telecommunication Union (ITU), the United Nations Industrial Development Organization (UNIDO), and the International Civil Aviation Organization (ICAO). On April 3, 2020, China was appointed one of the five nations to the UNHRC's Consultative Group (UN Watch 2020). In this position, China will be able to influence the selection of 17 or more UN human rights mandate-holders, who "investigate, monitor, and publicly report on either specific country situations, or on thematic issues in all parts of the world" (ibid).

As a permanent member of the UN Security Council, China has influence in the high politics of major decision-making in that body. However, at the bureaucratic and operational level, China's representation lags behind many other countries in the Council, non-P5 standing committee members included. Up until 2000, there was no Chinese representative on the panel on the United Nations Peace Operations (UN 2001). It was highlighted in 2016 that China had no role in the High Independent Panel for United Nations Peace Operations (HIPPO) (He 2016) and it remains the case. ${ }^{9}$ In comparison, China's presence and investment in UN peacekeeping has been increasingly matched in positions in the UNPKO upper hierarchy (Lynch 2016). Although China has provided more peacekeeping troops than all of the other members of the P5 combined since 2012, nevertheless, a Chinese national has yet to hold a senior post on any of the 16 current UNPKO missions, with the ratio of

\footnotetext{
${ }^{8}$ UN reformers have suggested that to change the near monopoly on first-tier job selection should be primarily based on merit, not nationality. The UN Charter expressly forbids UN civil servants from seeking or receiving "instructions from any government or from any other authority external to the Organization." The UN General Assembly explicitly stated in 1992 that there should be "no monopoly on senior posts by nationals of any State or group of States." Major powers tend to pressure the UN Secretary General to fill his cabinet with their political appointees, which, the reformers complain, undermines institutional independence.

9 Xin He, from the Chinese Peacekeeping Training Centre in Langfang, has stated that by 2016, for instance, of the six expert panels nominated by the UN since 2000 to review and advise on UN peacekeeping affairs, China had only been invited to participate in two (He 2016; 2019). See also UN Security Council Committees, Working Groups and Ad Hoc Bodies, https://www.un.org/securitycouncil/content/ committees-working-groups-and-ad-hoc-bodies.
} 
Chinese appointments to senior ranking posts in DPKO remaining lower than that of other major powers.

\section{Concluding remarks}

To afford sufficiently convincing explanations to diffusion of both power and norms in the complex dynamical systems that characterize transition, International Relations Theorizing needs to develop sophisticated analytical tools. With a focus on the dynamics of contestation and (re)negotiation of global power relations in an evolving process of power distribution and norm diffusion, the three layers, or subprocesses in dynamical systems - unpacked here — of the complexity in China's current role in multilateral orders indicate the importance of regulating competition to manage rivalry, promoting cooperation as a way to meet the requirements of the realities of changing power relations, as well as global challenges that no state can cope with alone.

UN officials are likely to continue working closely with China to see that China's interest in increasing its contributions is sustained as a valuable part of a process of global institutional reform, a rebalancing and reinforcing of multilateral orders, with outcomes that reflect the participation and contribution of member states as well as their responsibilities. UN members including Germany, UK, France, and Japan, who are strong advocates of multilateralism, often appear more open than the United States to global power diffusion, though they expect the United States to continue its leadership role (Oliver and Williams 2016, 564-565; Kratochwil and Ruggie 1986). Shaping the characteristics of the Transitional Reformation processes of an emerging global order is a United States that remains not in the least at ease with a "live and let live" approach in dealing with the challenges rising powers (may) pose to liberal values of individual rights and market freedom.

US economic, military, technological and political primacy remains, though statistics show in a few areas the gap is narrowing between China and the United States (Naughton 2016; Clark 2011). Relations between China and the United States "will shape international order in the long term." As veteran global strategist Henry Kissinger opines, "[t]o contribute to the establishment of a more stable world order, we need to foster a perception of a joint enterprise that is not just about buying into an American project... the United States and China must strive to come to an understanding about the nature of their co-evolution." He emphasizes that it should be understood that China must be part of the co-evolution so that whatever economic contest the United States has with China "will be within a framework of a cooperative option" (Kissinger and Goldberg 2016; Kissinger 2020). Multilateral relations matter to peace and security, with China and the United States in the center of the arrangements.

The functions of multilateral frameworks are important for managing power relations in the sense that state behavior can be largely predictable with generative logics inherent in the ordering principles of multilateralism. The liberal assumption holds that self-motivated compliance occurs in multilateral institutions as if in a social construct founded on freedom and consent at the international level (Ruggie 
1992; Keohane 2002; Morse and Keohane 2014). Because of deference to rules, states regard the institutional exercise of authority as appropriate, even if multilateral decisions go against a state's narrow or short-term interests. In a foreign policy characterized by pragmatic and problem-solving approaches, China presents the possibility that states of any ideological persuasion can become partners to cooperate on a win-win basis (Yang 2013; Xi 2017). The selected three layers of complexity in China's role in multilateral orders indicate that as China's shaping of the dynamics of contestation and (re)negotiation of global relation is increasing, its progress remains at least in part restricted. The restriction lies in China's limitations to date in fully articulating viable, desirable, alternative values, a global logic with which to anchor, and from which to express, its continuing participation in multilateral orders.

\section{Compliance with ethical standard}

Conflict of interest The author declares that there is no conflict regarding the publication of this article.

\section{References}

Acharya, Amitav. 2004. How ideas spread whose norms matter? Norm localization and institutional change in Asian regionalism. International Organization 58 (Spring): 239-275.

Allison, Graham. 2018. Destined for war: can America and China escape Thucydides' trap? New York: Houghton Mifflin.

Allison, Graham. 2015. The Thucydides trap: are the U.S. and China headed for war? The Atlantic. https://www.theatlantic.com/international/archive/2015/09/united-states-china-war-thucydides -trap/406756/. Accessed 2 Apr 2020.

Allison, Graham, Robert Blackwill, and Ali Wyne. 2013. Lee Kuan Yew: the grand master's insights on China, the United States, and the world. Belfer Center Studies in International Security.

Annan, Koffi. 2009. Problems without passports. Foreign Policy. https://foreignpolicy.com/2009/11/09/ problems-without-passports/. Accessed 2 Apr 2020.

Burley, Anne-Marie. 1993. Regulating the world: multilateralism, international law, and the protection of the new deal regulator state. In Multilateralism Matters, ed. John Ruggie, 125-136. New York: Columbia University Press.

Checkel, Jeffrey. 2001. Why comply? Social learning and European identity change. International Organization 55 (3): 553-588.

Chen, Zheng. 2016. China and the responsibility to protect. Journal of Contemporary China 25 (101): 686-700.

Cheng-Chia, Tung, and Alan H. Yang. 2020. How China is remaking the UN in its own image. The Diplomat. https://thediplomat.com/2020/04/how-china-is-remaking-the-un-in-its-own-image/. Accessed 11 Apr 2020.

Chin, Gregory T. 2016. Asian Infrastructure Investment Bank: governance innovation and prospects. Global Governance: A Review of Multilateralism and International Organizations 22 (1): 11-25. https://doi.org/10.1163/19426720-02201002.

Chin, Gregory T. 2019. The Asian Infrastructure Investment Bank-new multilateralism: early development, innovation, and future agendas. Global Policy 10 (4): 569-581.

Clark, Ian. 2011. China and the United States: a succession of hegemonies? International Affairs 87 (1): 13-28.

Clark, Ian. 2014. International society and China: the power of norms and the norms of power. The Chinese Journal of International Politics 7 (3): 315-340. https://doi.org/10.1093/cjip/pot014.

Contessi, Nicola. 2014. Multilateralism. In Oxford companion to international relations, ed. Joel Krieger, 96-101. New York: Oxford University Press. 
Drezner, Daniel W. 2007. All politics is global: explaining international regulatory regimes. Princeton: Princeton University Press.

Drezner, Daniel W. 2019a. Counter-hegemonic strategies in the global economy. Security Studies 28(3):505-531. https://doi.org/10.1080/09636412.2019.1604985.

Drezner, Daniel W. 2019b. Who is the real revisionist in the global political economy? The Washington Post, June 4.

Finnemore, Martha, and Kathryn Sikkink. 1998. International norm dynamics and political change. International Organization 52 (4): 887-917.

Foot, Rosemary. 2020. China, the United Nations, and human protection: beliefs, power, image. Oxford: Oxford University Press.

Foot, Rosemary, and Andrew Walter. 2011. China, the United States, and global order. New York: Cambridge University Press.

Garwood-Gowers, Andrew. 2016. China's responsible protection concept: reinterpreting the responsibility to protect $(\mathrm{R} 2 \mathrm{P})$ and military intervention for humanitarian purposes. Asian Journal of International Law 6(1): 89-118.

Garwood-Gowers, Andrew. 2012. China and the "responsibility to protect": the implications of the Libyan intervention. Asian Journal of International Law 2(2):375-393. https://doi.org/10.1017/S2044 25131200015X.

Gladstone, Rich. 2020. U.N. Security Council "missing in action" in coronavirus fight. https://www. nytimes.com/2020/04/02/world/americas/coronavirus-united-nations-guterres.html. Accessed 2 Apr 2020.

Gu, Bin. 2017. Chinese multilateralism in the AIIB. Journal of International Economic Law 20: 137158. https://doi.org/10.1093/jiel/jgx006.

Guterres, Antonio. 2010. https://www.un.org/en/coronavirus/un-secretary-general. Accessed 31 Mar 2020.

He, Yin. 2016. UN peacekeeping affairs and China's discursive power. World Economics and Politics 11: 41-62.

He, Yin. 2019. China rising and its changing policy on UN peacekeeping. In United Nations peace operations in a changing global order, ed. Cefric de Coning, and Peter Mateja, 253-276. London: Palgrave Macmillan.

Hinshaw, Drew, and Lukas I. Alpert. 2020. U.S. allies leave WHO funding gap unfilled as China and others step up. The Wall Street Journal. April 24, 2020.

Horvath, Balazs. 2016. Identifying development dividends along the Belt and Road initiative: complementarities and synergies between the Belt and Road initiative and the sustainable development goals. In 2016 high-level policy forum on global governance: 'Belt \& Road': a new path to regional development, scoping paper 1. https://www.undp.org/content/dam/china/docs/Publications/UNDPCH-BRI\%202017\%20Scoping\%20Paper1\%20\%EF\%BC\%88Final\%EF\%BC\%89.pdf. Accessed 31 Mar 2020.

Humphrey, Chris. 2020. From drawing board to reality: the first four years of operations at the Asian Infrastructure Investment Bank and New Development Bank. In Working Paper of the G-24 \& Global Development Policy Center of Boston University, April.

Hurd, Ian. 2007. Breaking and making norms: American revisionism and crises of legitimacy. International Politics 44(2):194-213.

Hurrell, Andrew. 2007a. One world, many worlds: the place of regions in the study of international society. International Affairs 83(1):127-146.

Hurrell, Andrew. 2007b. On global order: power, values, and the constitution of international society. Oxford: Oxford University Press.

Hurrell, Andrew. 2010. Brazil: what kind of rising state in what kind of institutional order? In Rising states, rising institutions, ed. Alan S. Alexandroff, and Andrew F. Cooper, 128-150. Brookings Institution: Washington DC.

Hurrell, Andrew. 2003. Order and justice in international relations: what is at stake? In Order and justice in international relations, ed. Rosemary Foot, John Lewis Gaddis, and Andrew Hurrell, 24-48. Oxford: Oxford University Press.

Ikenberry, G John. 2008. The rise of China and the future of the West: can the liberal system survive? Foreign Affairs 87(1):23-37.

Ikenberry, G. John, and Charles A. Kupchan. 1990. Socialization and hegemonic power. International Organization 44(3):283-315. 
Information Office of the State Council of PRC. 2013. Defence White Paper: the diversified employment of China's armed forces. https://en.people.cn/90786/8209362.html. Accessed 2 Apr 2020.

Johnston, Alastair Iain. 2019. China in a world of orders: rethinking compliance and challenge in Beijing's international relations. International Security 44(2):9-60.

Kahler, Miles. 1992. Multilateralism with small and large numbers. International Organization 46(3):681-708.

Kahler, Miles. 2018. Global governance: three futures. International Studies Review 20:239-246.

Keohane, Robert. 2002. Power and governance in a partially globalized world. London: Routledge.

Kim, Samuel. 1979. China, the United Nations and world order. Princeton: Princeton University Press.

Kim, Samuel. 1998. Chinese foreign policy in theory and practice. In China and the world: Chinese foreign policy faces the new millennium, ed. Samuel Kim, 3-33. Boulder: Westview Press.

Kirshner, Johnathan. 2019. Offensive realism, Thucydides traps, and the tragedy of unforced errors: classical realism and US-China relations. China International Strategy Review 1(1):51-63.

Kissinger, Henry. 2020. The coronavirus pandemic will forever alter the world order. Wall Street Journal. https://www.wsj.com/articles/the-coronavirus-pandemic-will-forever-alter-the-world-order-11585 953005. Accessed 2 Apr 2020.

Kissinger, Henry, and Jeffrey Goldberg. 2016. World chaos and world order: conversations with Henry Kissinger. The Atlantic. https://www.theatlantic.com/international/archive/2016/11/kissinger-order -and-chaos/506876/. Accessed 2 Apr 2020.

Kratochwil, Friedrich, and John Gerard Ruggie. 1986. International organization: a state of the art on an art of the state. International Organization 40(4):753-775.

Kratochwil, Friedrich. 1993. The embarrassment of changes: neo-realism as the science of realpoltik without politics. Review of International Studies 19(1):63-80.

Lynch, Colum. 2016. China eyes ending western grip on top U.N. jobs with greater control over blue helmets. Foreign Policy. https://foreignpolicy.com/2016/10/02/china-eyes-ending-western-grip-ontop-u-n-jobs-with-greater-control-over-blue-helmets/. Accessed 30 Mar 2020.

Mahbubani, Kishore. 2020. Has China won?: the Chinese challenge to American primacy. New York: Hachette Book Group, Inc.

Marquis, Christopher. 2001. Satisfied with U.N. reforms, helms relents on back dues. The New York Times. https://www.nytimes.com/2001/01/10/world/satisfied-with-un-reforms-helms-relents-onback-dues.html. Accessed 2 Apr 2020.

Martina, Michael, and David Brunnstrom. 2015. China's Xi says to commit 8,000 troops for U.N. peacekeeping force. Reuters. https://www.reuters.com/article/us-un-assembly-china/chinas-xi-says-tocommit-8000-troops-for-u-n-peacekeeping-force-idUSKCNORS1Z120150929. Accessed 30 Mar 2020.

Mearsheimer, John J. 2010. The gathering storm: China's challenge to US power in Asia. The Chinese Journal of International Politics 3(4):381-396. https://doi.org/10.1093/cjip/poq016.

Milner, Helen V., and Robert O. Keohane. 1996. Internationalization and domestic politics: an introduction. In Internationalization and domestic politics, ed. Robert O. Keohane, and Helen V. Milner, 3-24. Cambridge: Cambridge University Press.

Morrison, Rodney J. 1993. The London monetary and economic conference of 1933: a public goods analysis. American Journal of Economics and Sociology 52(3):307-321.

Morse, Julia C., and Robert Keohane. 2014. Contested multilateralism. The Review of International Organization 9:385-412.

Naughton, Barry. 2016. Economic growth from high-speed to high-quality. In The China reader:rising power, ed. David Shambaugh, 104-116. New York: Oxford University Press.

Nye, Joseph S., Jr. 2020. Power and interdependence with China. The Washington Quarterly 43(1):7-21.

Nye, Joseph S., Jr. 2017. The Kindleberger Trap. https://www.project-syndicate.org/. Accessed 30 Mar 2020.

Oliver, Tim, and Michael John Williams. 2016. Special relationships in flux: Brexit and the future of the US-EU and US-UK relationships. International Affairs 92(3):547-567.

Paal, Douglas. 2011. China, mugged by reality in Libya, again. Carnegie Endowment for International Peace. https://carnegieendowment.org/2011/04/11/china-mugged-by-reality-in-libya-again-pub43554. Accessed 31 Mar 2020

Pauley, Logan. 2018. China takes the lead in UN peacekeeping. The Diplomat. https://thediploma t.com/2018/04/china-takes-the-lead-in-un-peacekeeping/. Accessed 1 Apr 2020. 
Quayle, Peter, and Xuan Gao. 2018. AIIB yearbook of international law. 2018: good governance and international financial institutions. https://www.aiib.org/en/about-aiib/who-we-are/yearbook/_downl oad/2018-AIIB-Legal-Yearbook.pdf. Accessed 26 Apr 2020.

Roberts, Adam. 2003. Order/justice issues at the United Nations. In Order and justice in international relations, ed. Rosemary Foot, John Lewis Gaddis, and Andrew Hurrell, 49-79. Oxford: Oxford University Press.

Ruggie, John Gerard. 1992. Multilateralism: the anatomy of an institution. International Organization 46(3):561-598.

Schweller, Randall. 2018. Opposite but compatible nationalisms: a neoclassical realist approach to the future of US-China relations. The Chinese Journal of International Politics 11(1):23-48.

Schweller, Randall. 2015. Rising powers and revisionism in emerging international orders. Valdai Papers $\# 16$.

Shendruk, Amanda, Laura Hillard, and Diana Roy. 2020. Funding the United Nations: what impact do U.S. contributions have on UN agencies and programs? Council on Foreign Relations. https://www. cfr.org/article/funding-united-nations-what-impact-do-us-contributions-have-un-agencies-and-progr ams. Accessed 8 June 2020.

Shi, Yinhong 2015. China's complicated foreign policy. European Council on Foreign Relations. https ://www.ecfr.eu/article/commentary_chinas_complicated_foreign_policy311562. Accessed 30 Mar 2020.

Tasdall, Simon. 2019. Rivals in the scramble to be the world's 21st-century superpower. The Guardian. https://www.theguardian.com/us-news/2019/oct/19/global-battle-power-putin-trump-syria. Accessed 11 Apr 2020.

Trump, Donald. 2017. The inaugural address. https://www.whitehouse.gov/briefings-statements/theinaugural-address/. Accessed 1 Apr 2020.

Trump, Donald. 2019. Remarks by President Trump to the 74th session of the United Nations General Assembly. https://www.whitehouse.gov/briefings-statements/remarks-president-trump-74th-sessi on-united-nations-general-assembly/. Accessed 2 Apr 2020.

U.S. Department of Defense. 2018. Summary of the 2018 National Defense Strategy of The United States of America: sharpening American military's competitive edge. https://dod.defense.gov/Portals/1/ Documents/pubs/2018-National-Defense-Strategy-Summary.pdf. Accessed 2 April 2020.

UN. 2020. Contributions received for 2020 for the United Nations regular budget. https://www.un.org/en/ $\mathrm{ga} /$ contributions/honourroll.shtml. Accessed 8 June 2020.

UN News. 2015. https://news.un.org/en/story/2015/09/510192-chinas-president-urges-un-general-assem bly-put-new-development-agenda-action. Accessed 1 May 2020.

UN News. 2016. https://www.un.org/development/desa/en/news/policy/building-belt-road-towards-sdgs. html. Accessed 1 May 2020.

UN News. 2019. At China's Belt and Road Forum, Guterres calls for inclusive, sustainable and durable development. https://news.un.org/en/story/2019/04/1037381. Accessed 1 May 2020.

UN Watch. 2020. China Joins U.N. human rights panel. https://unwatch.org/chinaunhrc/. Accessed 4 Apr 2020.

UNSG. 2017. Remarks at the opening of the belt and road forum. https://www.un.org/sg/en/content/sg/ speeches/2017-05-14/secretary-general\%E2\%80\%99s-belt-and-road-forum-remarks. Accessed 1 May 2020.

United Nations Peacekeeping. Our history. https://peacekeeping.un.org/en/our-history. Accessed 2 Apr 2020.

Waltz, Kenneth N. 2000. Structural realism after the cold war. International Security 25(1):5-41.

Weiss, Thomas. 2012. What's wrong with the United Nations, and how to fix it. Cambridge, UK: Polity Press.

White House. 2017a. National security strategy of the United States of America. https://www.whitehouse .gov/wp-content/uploads/2017/12/NSS-Final-12-18-2017-0905.pdf. Accessed 2 Apr 2020.

White House. 2017b. Press briefing on President Trump's upcoming visit to Poland and Germany. Accessed 2 Apr 2020.

Xi, Jinping. 2015a. China is here for peace. Remarks by H.E. Xi Jinping of the People's Republic of China at the United Nations Peacekeeping Summit. https://www.fmprc.gov.cn/mfa_eng/wjdt_66538 5/zyjh_665391/t1305410.shtml. Accessed 30 Mar 2020.

$\mathrm{Xi}$, Jinping. 2015b. Working together to forge a new partnership of win-win cooperation and create a community of shared future for mankind. Statement at the General Debate of the 70th Session of the 
UN General Assembly, September 28. New York. https://www.fmprc.gov.cn/mfa_eng/topics_66567 8/xjpdmgjxgsfwbcxlhgc170znxlfh/t1304144.shtml. Accessed 30 Mar 2020.

$\mathrm{Xi}$, Jinping. 2015c. Toward a community of common destiny and a new future for Asia: keynote speech by H.E. Xi Jinping. Boao Forum for Asia Annual Conference. https://english.boaoforum.org/hynew /19353.jhtml. Accessed 30 Mar 2020.

Xi, Jinping. 2017. Xi Jinping's keynote speech at the World Economic Forum. https://www.china.org.cn/ node_7247529/content_40569136.htm. Accessed 30 Mar 2020.

Xinhua. 2015. Xi Jinping emphasizes, at the 27th CCP Politburo collective study session, the importance to promote fair and just global governance system for a favorable condition for China's development and world peace. https://www.xinhuanet.com//politics/2015-10/13/c_1116812159.htm. Accessed 30 Mar 2020.

Xinhua. 2018. Xi urges breaking new ground in major country diplomacy with Chinese characteristics. https://www.xinhuanet.com/english/2018-06/24/c_137276269.htm.Accessed 30 Mar 2020.

Yang, Suzanne Xiao. 2014. China in UN Security Council decision-making on Iraq: conflicting understandings, competing preferences. Routledge New International Series. London: Routledge.

Yang, Jiechi. 2013. Implementing the Chinese dream. National Interest. https://nationalinterest.org/ commentary/implementing-the-chinese-dream-9026. Accessed 2 Apr 2020.

Zhang, Yongjin. 1998. China in international society since 1949: alienation and beyond. Basingstoke: Macmillan.

Zhang, Yongjin. 2016. China and liberal hierarchies in global international society: power and negotiation for normative change, special issue: Chinese foreign policy on trial: contending perspective? International Affairs 92(4):795-816.

Zhao, Suisheng. 2018. A revisionist stakeholder: China and the post-world war II world order. Journal of Contemporary China 27(113):643-658. https://doi.org/10.1080/10670564.2018.1458029.

Zhou, Bo. 2017. How China can improve UN peacekeeping. Foreign Affairs. https://www.foreignaffairs. com/articles/china/2017-11-15/how-china-can-improve-un-peacekeeping. Accessed 4 Apr 2020. 